\title{
Annotations
}

\section{Child care and the family doctor}

Ten years ago it really seemed as though we were on the brink of great new developments in child health in this country. The British Paediatric Association had just published Paediatrics in the seventies, ${ }^{1}$ the Brotherston and Court committees were reviewing the child health services, and there was much talk of integration and of new and wider opportunities. These high expectations have gradually given way to despondency and cynicism, as economic stringency and harsh political doctrine have blunted the edge of enthusiasm. Procrastination over the future of child health care in schools and clinics, hostility to the paediatric orientation of clinical medical officers, and national priority for geriatrics and psychiatry at the expense of child health have all conspired to erode confidence and create an atmosphere of disillusion. Attempts to persuade government and the public that children are the seed corn which must be protected at all costs have fallen on stony ground, on to which the Black report ${ }^{2}$ dropped with a dull thud. It is small wonder that the heady optimism engendered by the Court report ${ }^{3}$ has largely evaporated and that the once bright future seems shrouded in gloom.

\section{A new plan of action}

Into this sombre scene has now come a fresh ray of sunlight. The Working Party on Child Care established by the Royal College of General Practitioners has produced a forward-looking report Healthier children-thinking prevention ${ }^{4}$ with recommendations which, if implemented, would transform the health care of children in this country. It endorses and extends the broad intent of the Court $^{3}$ and Brotherston ${ }^{5}$ reports, stressing the importance of prevention, and placing the main responsibility for child health squarely on the shoulders of the family doctor. It affirms boldly what is tacitly recognised but seldom referred to openly, that present-day general practice, despite its undoubted strengths and cost-effectiveness, is a hotchpotch of differing attitudes and standards which do not match up to the needs of modern preventive and therapeutic child care.

The Working Party proceeds to describe in considerable detail a pattern of family practice which, if universally adopted, would ensure a uniformly high level of primary care for children equal to, or surpassing, the very best standards of today. Implementation would necessitate fundamental changes in the role of the general practitioner, who would have to acquire different attitudes of mind and new professional skills. Active health promotion with regular review of results, wellmaintained records, ready accessibility at all times, and effective teamwork are some of the components of good practice as envisaged by the Working Party.

\section{The Court report}

This new report convincingly makes the case for the primary care of children to be undertaken by generalist family doctors rather than by paediatric specialists. The earlier report of the Committee on Child Health Services reached essentially the same conclusion, although it was misinterpreted by many as advocating the creation of primary care doctors who would specialise exclusively in paediatrics. In fact, the Committee's contention was that family doctors should have a sound knowledge and understanding of paediatric principle, and that where a number practised together, one or more might take a particular interest in developmental surveillance and preventive paediatrics. In retrospect, it was probably unwise to introduce the term 'general practitioner paediatrician' and to speculate about the proportion of his time to be spent with children, when the purpose was to stress the need for greater professional skill in the care of children, rather than to undermine the general basis of primary care. The Royal College of General Practitioners Working Party favours separate sessions for child health surveillance and recognises that in some practices the responsibility for such sessions may be taken by one of the partners or sometimes by a clinical medical officer trained according to the recommendations of the Forfar report ${ }^{6}$ and working as a member of the primary care team. The two reports are thus compatible in principle and in full accord in their belief that the general approach of the practitioner to all members of the family is of inestimable value in dealing with childhood problems, which so often have their origin in family relationships and lifestyle. 


\section{Can it be achieved?}

I have not read anything in recent years so heartening as this splendid report, which throws the great strength of the Royal College of General Practitioners into the struggle to create a better health service for British children. The critical question is whether family doctors throughout the land will accept its message and seize the future offered with both hands or whether it will founder like so many of its predecessors on the rocks of medical conservatism and official apathy. This may well represent the last real chance for our generation to set a new course to better standards of child health care and so to promote the interests of children and their parents, which have always been and must continue to be our first concern.

The opportunity is there but it is too early to rejoice, for promise is not achievement and, as the report says, actions speak louder than words. The Working Party of the Royal College of General Practitioners clearly believes that the recommendations are realistic and urges an immediate start to implementing them. The end of 1987 is suggested as the target date for attaining the main objectives and, although this may be considered impracticable, it

\section{Vision and reality}

The report Healther children-thinking prevention is a remarkable publication. For those familiar with The pilgrim's progress it is like seeing a vision of The Celestial City from the hill Difficulty. ${ }^{1}$

The contents have been carefully gathered, the style is clear, and the whole presentation infused with sincerity and purpose. The message to readers, and to the Royal College of General Practitioners, is that prevention should now become a first responsibility in the medical care of children.

The report first considers environmental factors which can help or hinder children's growth and health, and its conclusions support those of McKeown ${ }^{2}$ and Black: ${ }^{3}$ environmental advantage or disadvantage is the main determinant of children's health; the wide regional and neighbourhood differences are unacceptable; where needs are greatest, services are least satisfactory.

The late Ronald Mackeith would have been delighted by the report's developmental framework. It consists of a preface and conclusions, and between them 18 short, crisp chapters which deal with the reasons for setting prevention in primary care, the response required from contemporary practice, the does impart a desirable sense of urgency. Nevertheless, the requirement for additional financial expenditure will not endear the report to the Treasury in the present economic climate and much advocacy and hard groundwork will be needed. The brave new world is not yet here.

\section{References}

1 British Paediatric Association. Paediatrics in the seventies. Oxford: University Press, 1972.

2 Black D A K, chairman. Inequalities in health. Report of a research working group. London: DHSS, 1980.

3 Court S D M, chairman. Fit for the future. Report of the committee on child health services. London: HMSO, 1976.

4 Royal College of General Practitioners. Healthier children -thinking prevention. Report from General Practice No 22. London: RCGP, 1982.

5 Brotherston J H F, chairman. Towards an integrated child health service. Report of a Sub-Group on the Child Health Service of the Joint Working Party on the Integration of Medical Work. Edinburgh: HMSO, 1973.

6 Forfar J O, chairman. Report of Joint Working Party on the training of clinical medical officers in child health. Br Med J 1982; 284; 637-40.

Ross G MITCHELL
Department of Child Health,
University of Dundee,
Ninewells Hospital and Medical School,
Dundee DD1 $9 S Y$

team approach, and the new relationships between doctors, colleagues, parents, and children which will be called for.

Additional training is considered essential, and the requirements for the transitional and the established phases are well argued. Does the report then merit unreserved approval ? In a change of such extent and complexity, there are bound to be omissions. A cynic, unfamiliar with recent developments in general practice, might dismiss it as a well intentioned fantasy. I prefer to see it as prophetic vision, and to remember that 'where there is no vision the people perish'.

Why then did I add 'reality' to vision in the title? Because the gap between intention and implementation is wide and may be growing wider. Visionaries are also tempted to accept assumptions as evidence; to believe they have found a solution when they have only found a phrase. For example, the report states that 'the adverse effects on the children of parents who separate or divorce are well known'; in reality these effects have still to be uncovered.

Again it is implied that accurate monitoring of chronic childhood illness by general practitioners is 